nite. Many of the paragneisses and the amphibolites contain sulphides, mostly pyrite and pyrrhotite. The alkaline complex contains small amounts of søvite carbonatite and has no anomalous radioactivity. Some of the søvites are rich in large apatite crystals and some of the pegmatitic feldspars show weak schillerization and contain massive sky blue cancrinite.

\section{References}

Andrews, J. R., Bridgwater, D., Gulson, B. \& Watterson, J. 1971: Reconnaissance mapping of South-East Greenland between $62^{\circ} 30^{\prime} \mathrm{N}$ and $60^{\circ} 30^{\prime} \mathrm{N}$. Rapp. Gronlands geol. Unders. 35, 32-38.

Andrews, J. R., Bridgwater, D., Gormsen, K., Gulson, B., Keto, L. \& Watterson, J. 1973: The Precambrian of SouthEast Greenland, In Park, R. G. \& Tarney, J. (edit.) The Precambrian of Scotland and related rocks of Greenland, 143-156. Birmingham U.P.

Bridgwater, D. 1976: Nagssugtoqidian mobile belt in East Greenland. In Escher, A. \& Watt, W. S. (edit.) Geology of Greenland, 97-103. Copenhagen: Geol. Surv. Greenland.

Bridgwater, D. \& Gormsen, K. 1969: Geological reconnaissance of the Precambrian rocks of South-East Greenland. Rapp. Grønlands geol. Unders. 19, 43-50.

Bridgwater, D., Keto, L., McGregor, V. R. \& Myers, J. S. 1976: The Archaean gneiss complex of Greenland. In Escher, A. \& Watt, W. S. (edit.) Geology of Greenland, 18-75. Copenhagen: Geol. Surv. Greenland.
Chadwick, B., Dawes, P. R., Escher, J. C., Friend, C. R. L., Hall, R. P., Kalsbeek, F., Nielsen, T. F. D., Nutman, A. P., Soper, N. J. \& Vasudev, V. N. in press: The Proterozoic mobile belt in the Ammassalik region, South-East Greenland (The Ammassalik mobile belt): an introduction and re-appraisal. Rapp. Grønlands geol. Unders.

Escher, J. C. \& Nielsen, T. F. D. 1982: Reconnaissance mapping of the rocks between Uivaq $\left(63^{\circ} 03^{\prime} \mathrm{N}\right)$ and Bernstorffs Isfjord $\left(63^{\circ} 38^{\prime} \mathrm{N}\right)$, South-East Greenland. Rapp. Grønlands geol. Unders. 110, 77-80.

Escher, J. C. \& Nielsen, T. F. D. 1983: Archaean gneisses and supracrustal rocks of the Tingmiarmiut region, South-East Greenland. Rapp. Gronlands geol. Unders. 115, 79-82.

Escher, J. C., Kalsbeek, F., Larsen, O., Nielsen, T. F. D. \& Taylor, P. N. 1986: Reconnaissance dating of Archaean rocks from South-East Greenland. Rapp. Grønlands geol. Unders. 130, 90-95.

Escher, J. C., Friend, C. R. L. \& Hall, R. P. in press: The southern boundary of the East Greenland Proterozoic mobile belt: geology of the area between Umîvik and Isortoq. Rapp. Gronlands geol. Unders.

Hall, R. P., Hughes, D. J. \& Joyner, L. in press: Basic dykes of the southern Ammassalik region, South-East Greenland. Rapp. Grønlands geol. Unders.

Kalsbeek, F. \& Nielsen, T. F. D. 1987: Regional geological investigations in the Ammassalik district, South-East Greenland. Rapp. Grønlands geol. Unders. 135, 59-66.

Nielsen, T. F. D. \& Escher, J. C. 1985: Preparations for the South-East Greenland mapping project 1986-1987. Rapp. Grønlands geol. Unders. 125, 84-87.

\title{
Sedimentological studies of the fluviatile-shallow marine Upper Triassic to Lower Jurassic succession in Jameson Land, East Greenland
}

\author{
Gregers Dam
}

A three-year research fellowship programme supported by British Petroleum Development, London, was initiated in the summer of 1987 . The main subject of the study is the Upper Triassic to Lower Jurassic succession in Jameson Land, East Greenland. This stratigraphic interval includes the Kap Stewart and the Neill Klinter Formations which have many features in common with some of the largest coeval hydrocarbon reservoir formations known in N.W. Europe (e.g. Statfjord field).

The core of the project is a lithofacies analysis but ichnology, palynology, source-rock analyses and porosity/permeability analyses will be included where relevant. If possible, corresponding intervals from the Nor- wegian continental shelf will be included in the project. The aim of the project is:

(1) to provide detailed and regional facies models for the two formations. Special stress will be laid on the physical stratigraphic relations in order to ascertain if regional unconformities are present and what order of magnitude they may represent.

(2) to establish a reservoir geological model which might help in the understanding of comparable reservoirs in the Norwegian-Greenland region. Particular attention will be paid to the geometry of individual sand bodies. 


\section{Field work}

The field work in 1987 was carried out by one geological team and lasted for 5 weeks from late July to late August. Four localities were visited along the eastern margin of Jameson Land and in the southern part of Scoresby Land (fig. 1). Sedimentological studies involved detailed lithofacies and ichnofacies analyses as well as sampling for palynofacies analyses and porosity and permeability measurements.

\section{Regional setting}

The Mesozoic basins of East Greenland were formed in a failed rift system that was initiated in Carboniferous and Permian times (Surlyk et al., 1981). The rift is orientated north-south and is cut by major NW-SE cross-faults that developed in the Jurassic and led to progressive northward-stepping downfaulting of blocks (Surlyk, 1977). Jameson Land is situated on the block farthest to the south in the exposed part of the graben system. This is the largest block and has the most complete Mesozoic succession which is at least $5 \mathrm{~km}$ thick (Surlyk et al., 1981).

Throughout the Triassic the block was characterised mainly by continental rift deposition in an arid climate (Clemmensen, 1980). In Rhaetian - Hettangian times the basin was affected by cross-fault activity. To the north the basin was bounded by a NW-SE cross-fault in Kong Oscars Fjord (fig. 1). The southern boundary is unknown, but the continental fluvial deposits show that the palaeodrainage was towards the north, suggesting that a cross-fault was operative in Scoresby Sund (Surlyk et al., 1981). The basin was bounded to the west by the same major fault zone as the Triassic basin and to the east probably by a N-S elongated landmass including the present day Liverpool Land (Surlyk et al., 1981). The Rhaetian-Hettangian phase was dominated by fluvial and restricted marine deltaic sedimentation of the Kap Stewart Formation (Sykes 1974a; Clemmensen, 1976). The flora and presence of thin coal seams and rootlet horizons suggest that the climate had now become temperate and humid (Pedersen, 1976; Surlyk et al., 1981).

During Pliensbachian - Toarcian times the basin was transgressed by tidal and shelf deposits of the Neill Klinter Formation (Sykes, 1974b). These deposits are also restricted to Jameson Land and Scoresby Land and indicate that the basin was bounded by the same major fault zones as during Rhaetian - Hettangian times. However, the new data suggest that there may have been an opening of the basin to the south.

During Jurassic times the depositional environment

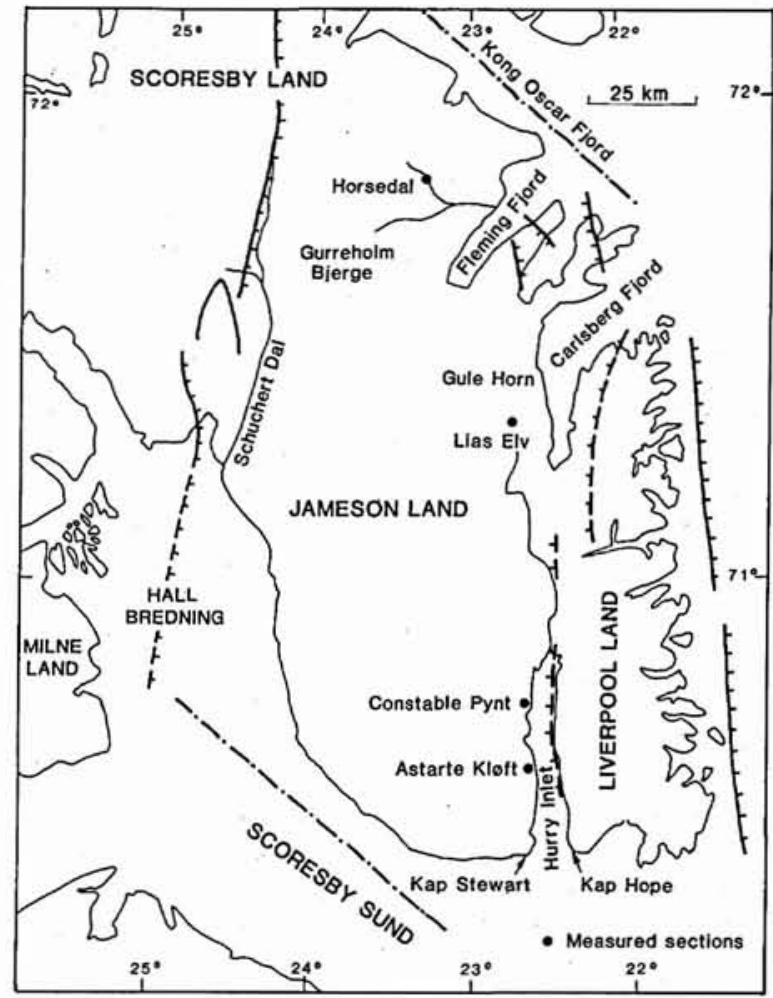

Fig. 1. Map of Jameson Land showing the localities of measured sections and major faults based on Surlyk et al. (1981).

changed from the tidal deposits of the Neill Klinter Formation to a shallow siliciclastic shelf and finally to a wide muddy shelf (Surlyk et al., 1981).

\section{Kap Stewart Formation}

The Rhaetian - Hettangian sediments of the Kap Stewart Formation (Rosenkrantz, 1929) were studied in two areas along the west coast of Hurry Inlet (Astarte Kløft and Constable Pynt) and in Horsedal in southern Scoresby Land (fig. 1). The sediments along Hurry Inlet are known for their well-preserved and extensive flora described in a series of papers by T. M. Harris, published from 1926 to 1937. Harris (1937) divided the upper 'plant-bearing' series of the formation into two macroplant zones; a lower Lepidopteris Zone and an upper Thaumatopteris Zone. Pedersen \& Lund (1980) made detailed palynological studies on the same localities in order to obtain a firmer dating of the macroplant zones of Harris by comparing spores and pollen from these zones with well-dated microfloras from northwestern Europe.

The formation is approximately $200 \mathrm{~m}$ thick along Hurry Inlet but well-exposed sections are present only 
in the upper $100 \mathrm{~m}$ in Astarte Kløft. At Constable Pynt the succession is poorly exposed but a virtually complete section through the formation is displayed. In Astarte Kløft and at Constable Pynt, fluvial-dominated delta plain facies associations occur which comprise fluvial-distributary channel sandstone, bank sandstone and interdistributary bay siltstone. Sykes (1974a) interpreted the sediments as being deposited in a low sinuosity non-braided river environment. The bank deposits occasionally show rootlet horizons; and plant debris and thin coal seams often occur in the interdistributary bay sediments. Palaeocurrent data from the distributary channels, although often very complex, suggest a general eastern to southern source area, the channels probably draining a landmass over present day Liverpool Land and a more southern area during this period.

In southern Scoresby Land the Kap Stewart Formation has an estimated thickness of approximately $350 \mathrm{~m}$ (Surlyk et al., 1973). In Horsedal the uppermost $265 \mathrm{~m}$ are accessible often with good exposures. The sediments are characterised by wave-dominated delta-facies associations and have been interpreted by Clemmensen (1976) as tidally influenced deltaic deposits. Delta plain facies comprise fluvial-distributary channel sandstone and interdistributary bay mudstone and siltstone. Very little plant debris has been found in Horsedal. However, rootlet horizons and thin coal seams occur locally. The delta-front facies comprises 4-8 $\mathrm{m}$ thick coarseningupwards sequences. The fine members at the base of the delta front are dominated by siltstone often with storm sand layers. The fine members grade up into well-sorted fine- to medium-grained sandstone which exhibits wave ripple lamination, horizontal stratification and crossbedding. The sequences are often erosively overlain by medium- to coarse-grained fluvial-distributary channel sandstone. Sequences not topped by fluvial-distributary channels may represent longshore shoals formed under the influence of wave action. Palaeocurrent data from distributary channels suggest a source area to the northnorth-west. Crest-line orientations of wave ripples indicate that the palaeo-coastline had a general E-W to NW-SE trend.

No invertebrate body fossils were found in the formation, and only a few unidentifiable trace fossils were observed at the three localities examined. The upper boundary to the overlying Neill Klinter Formation is well exposed in Horsedal and seems to be much more gradual here than along the Hurry Inlet where the Kap Stewart Formation is sharply overlain by probable shoreface deposits of the Rævekløft Member.

\section{Neill Klinter Formation}

The Pliensbachian - Toarcian sediments of the Neill Klinter Formation (Rosenkrantz, 1929; Lund \& Pedersen, 1985) were studied in three areas; at Neill Klinter (Astarte Kløft and Constable Pynt), in Lias Elv (east of Carlsberg Fjord), and in southern Scoresby Land (fig. 1). The formation consists of three members (Surlyk $e t$ al., 1973): the Rævekløft Member (base), the Gule Horn Member and the Ostrea Elv Member (top). These three members will be considered in turn.

Ravekløft Member. Deposition was initiated with the probable shoreface deposits of the Rævekløft Member. This member is approximately $9 \mathrm{~m}$ thick at Constable Pynt, thinning northwards to disappear entirely south of Carlsberg Fjord (Surlyk et al., 1973). It is composed of poorly-sorted medium- to very coarse-grained sandstone and contains a rich Pliensbachian marine fauna, particularly in the lower part (Rosenkrantz, 1934; Donovan, 1957). Large-scale trough and planar cross-stratification indicate north-east flowing currents.

Gule Horn Member. The Gule Horn Member is approximately $195 \mathrm{~m}$ thick along the west coast of Hurry Inlet where it overlies the Rævekløft Member (Surlyk et al., 1973). To the north, in Lias Elv and Horsedal the member is approximately $200 \mathrm{~m}$ thick and directly overlies the Kap Stewart Formation. The sediments in Astarte Kløft and at Constable Pynt are characterised by tidal and shelf facies associations and have earlier been interpreted as offshore estuarine in origin (Sykes, 1974b). The tidal sediments are dominated by lenticular-, wavyand flaser-bedded very fine to fine sandstone, alternating coarse sandstone and mudstone and cross-bedded medium- to coarse-grained sandstone. No indications of subaerial exposure were observed in the Gule Horn Member at Neill Klinter and probably the sediments were laid down on subtidal shoals. The shelf sediments are dominated by siltstone occasionally with storm sand layers. At the top of the succession at Constable Pynt possible tidal ridge deposits are present, suggesting that the palaeoshelf may have been both storm and tide dominated. Palaeocurrent data measured on small- and large-scale cross-stratification are strongly bipolar from $\mathrm{N}-\mathrm{S}$ to NE-SW, but herringbone structures are seldom observed. The deposits of the Gule Horn Member at Lias Elv are very similar to the deposits along Neill Klinter. Palaeocurrent data from Lias Elv are also strongly bipolar from north-east and south-west. The crests of the wave ripples at Lias Elv are usually orientated ESE-WNW, possibly suggestive of an ESEWNW trending coastline. 
At Horsedal there seems to be a gradual transition between the Kap Stewart Formation and the Gule Horn Member. Wave-generated facies associations continue to dominate the deposits but bipolar palaeocurrent directions and current-generated wavy and flaser bedding indicate an increasing tidal influence in the Gule Horn Member. Shelf facies associations are not as common as to the south, and the local presence of rootlet horizons and thin coal seams indicate a more coastal position for the deposits in Horsedal. Palaeocurrent data are bipolar with currents from north-north-east and south-southwest. The crests of the wave ripples in Horsedal are orientated ESE-WSW pointing to the same palaeocoastline orientation as in the Kap Stewart Formation.

Ostrea Elv Member. The tidal deposits of Gule Horn Member pass gradually throughout the area into the sediments of the Ostrea Elv Member. This member is approximately $90 \mathrm{~m}$ thick (Surlyk et al., 1973) and is composed of very well sorted fine- to medium-grained sand. Bioturbation and the uniform grain size of the sediments often obscure primary sedimentary structures but locally wave ripples and large-scale cross-bedding are present. At the very top of the sequence at Horsedal a well exposed section with hummocky cross-stratification is present, which may indicate a storm-dominated shelf environment. The marine fauna present in several horizons of the Ostrea Elv Member is listed by Rosenkrantz (1934) and Donovan (1957).

The Neill Klinter Formation contains a wide variety of trace fossils which represent a wide range of behavioural patterns. A classification of behaviour gives at least three ethological groups (domichnia, repichnia and fodichnia), whereas the spatial distribution of the traces allows recognition of several trace fossil assemblages. These can possibly be followed throughout Jameson Land and southern Scoresby Land.

\section{Laboratory work and future studies}

The main objective for future work is the development of detailed and regional facies models for the sedimentary history of the Jameson Land basin during Late Triassic and Early Jurassic times. Detailed ichnofacies studies will be incorporated in the facies models. In order to evaluate the reservoir potential, porosity and permeability analyses will be carried out. Special emphasis will be placed on the correlation between reservoir properties and lithofacies. Palynological studies and source rock-analysis will be made on samples from shale sequences. Detailed biostratigraphical studies of the two formations in southern Scoresby Land are important as the precise age relations are very poorly known. Field work is planned to be continued in 1988 and 1989. In 1988 the main investigation will be in the areas along Hurry Inlet and Carlsberg Fjord near the eastern basin margin, in Schuchert Dal to the west, and around Gurreholm Bjerge to the north.

Acknowledgements. The project is supported by British Petroleum Development, London. F. Surlyk, L. Stemmerik and H. C. Larsen made helpful criticisms of the manuscript and T. C. R. Pulvertaft kindly improved the English.

\section{References}

Clemmensen, L. B. 1976: Tidally influenced deltaic sequences from the Kap Stewart Formation (Rhaetic-Liassic), Scoresby Land, East Greenland. Bull. geol. Soc. Denmark 25, $1-13$.

Clemmensen, L. B. 1980: Triassic rift sedimentation and palaeogeography. Bull. Grønlands geol. Unders. 136, 72 pp.

Donovan, D. T. 1957: The Jurassic and Cretaceous Systems in East Greenland. Meddr Grønland 155, 214 pp.

Harris, T. M. 1937: The fossil flora of Scoresby Sound, East Greenland. 5. Stratigraphic relations of the plant beds. Meddr Grønland 112(2), 1-114.

Lund, J. J. \& Pedersen, K. R. 1985: Palynology of the marine Jurassic formations in the Vardekløft ravine, Jameson Land, East Greenland. Bull. geol. Soc. Denmark 33, 371-399.

Pedersen, K. R. 1976: Fossil floras of Greenland. In Escher, A. \& Watt, W. S. (edit.) Geology of Greenland, 529-535. Copenhagen: Geol. Surv. Greenland.

Pedersen, K. R. \& Lund, J. J. 1980: Palynology of the plantbearing Rhaetian to Hettangian Kap Stewart Formation, Scoresby Sund, East Greenland. Rev. Palaeobot. Palynol. 31, 1-69.

Rosenkrantz, A. 1929: Preliminary account of the geology of the Scoresby Sound district. In Koch, L. The geology of East Greenland. Meddr Grønland 73(2), 135-154.

Rosenkrantz, A. 1934: The Lower Jurassic rocks of East Greenland. Pt. I. Meddr Grønland 110(1), 122 pp.

Surlyk, F. 1977: Jurassic basin evolution of East Greenland. Nature, Lond. 274, 130-133.

Surlyk, F., Callomon, J. H., Bromley, R. G. \& Birkelund, T. 1973: Stratigraphy of the Jurassic - Lower Cretaceous sediments of Jameson Land and Scoresby Land, East Greenland. Bull. Grønlands geol. Unders. 105 (also Meddr Grønland 193,5), $76 \mathrm{pp}$.

Surlyk, F., Clemmensen, L. B. \& Larsen, H. C. 1981: PostPaleozoic evolution of the East Greenland continental margin. In Kerr, J. W. \& Ferguson, A. J. (edit.) Geology of the North Atlantic Borderlands. Mem. Can. Soc. Petrol. Geol. 7, 611-645.

Sykes, R. M. 1974a: Sedimentological studies in southern Jameson Land, East Greenland. I. Fluviatile sequences in the Kap Stewart Formation (Rhaetic-Hettangian). Bull. geol. Soc. Denmark 23, 203-212.

Sykes, R. M. 1974b: Sedimentological studies in southern Jameson Land, East Greenland. II. Offshore-estuarine regressive sequences in the Neill Klinter Formation (Pliensbachian - Toarcian). Bull. geol. Soc. Denmark 23, 213-224. 